\title{
Recent glacier retreat in the Caucasus Mountains, Russia, and associated increase in supraglacial debris cover and supra-/proglacial lake development
}

\author{
C.R. STOKES, ${ }^{1 *}$ V. POPOVNIN, ${ }^{2}$ A. ALEYNIKOV, ${ }^{2}$ S.D. GURNEY, ${ }^{1}$ \\ M. SHAHGEDANOVA ${ }^{1}$ \\ ${ }^{1}$ Landscape and Climate Research Group, Department of Geography, The University of Reading, Reading RG6 6AB, UK \\ E-mail: c.r.stokes@reading.ac.uk \\ ${ }^{2}$ Geographical Faculty, Moscow State University, Leninskiye Gory, 119992 Moscow, Russia
}

\begin{abstract}
This paper reports changes in supraglacial debris cover and supra-/proglacial lake development associated with recent glacier retreat (1985-2000) in the central Caucasus Mountains, Russia. Satellite imagery (Landsat TM and ETM+) was used to map the surface area and supraglacial debris cover on six neighbouring glaciers in the Adylsu valley through a process of manual digitizing on a false-colour composite of bands 5, 4, 3 (red, green, blue). The distribution and surface area of supraglacial and proglacial lakes was digitized for a larger area, which extended to the whole Landsat scene. We also compare our satellite interpretations to field observations in the Adylsu valley. Supraglacial debris cover ranges from $<5 \%$ to $>\mathbf{2 5} \%$ on individual glaciers, but glacier retreat between 1985 and 2000 resulted in a 3-6\% increase in the proportion of each glacier covered by debris. The only exception to this trend was a very small glacier where debris cover did not change significantly and remote mapping proved more difficult. The increase in debris cover is characterized by a progressive upglacier migration, which we suggest is being driven by focused ablation (and therefore glacier thinning) at the up-glacier limit of the debris cover, resulting in the progressive exposure of englacial debris. Glacier retreat has also been accompanied by an increase in the number of proglacial and supraglacial lakes in our study area, from 16 in 1985 to 24 in 2000, representing a 57\% increase in their cumulative surface area. These lakes appear to be impounded by relatively recently lateral and terminal moraines and by debris deposits on the surface of the glacier. The changes in glacier surface characteristics reported here are likely to exert a profound influence on glacier mass balance and their future response to climate change. They may also increase the likelihood of glacier-related hazards (lake outbursts, debris slides), and future monitoring is recommended.
\end{abstract}

\section{INTRODUCTION}

Mountain glaciers are a relatively reliable indicator of climate change, and their recent decline across the world has been linked to global warming (Barry, 2006). Arguably the most serious consequence of their shrinkage is the cumulative impact on global sea-level rise (e.g. Rignot and others, 2003), but the retreat of mountain glaciers has more localized consequences, affecting the geomorphology and hydrology of the glacial valleys which they occupy (Kaser and others, 2003; Fischer and others, 2006).

In this paper, we explore the local impacts of glacier retreat in the Caucasus Mountains, Russia, focusing specifically on the changes in supraglacial debris cover and the development of supra-/proglacial lakes. Several studies indicate that these phenomena are intimately linked with glacier retreat (Ageta and others, 2000). It is also known that glacial lakes can cause locally higher rates of ablation on debris-covered glaciers and that this can result in thermokarst processes and can lead to further glacier retreat (Benn and others, 2000). Moreover, glacial lakes, and particularly those that are dammed by ice-cored moraine, are a

*Present address: Department of Geography, University of Durham, South Road, Durham DH1 3LE, UK. Email: c.r.stokes@durham.ac.uk. potentially serious threat to human life because such dams can be prone to catastrophic failure (cf. Richardson and Reynolds, 2000).

Monitoring ongoing changes in glacier retreat, supraglacial debris cover and glacial lake development is therefore an important requirement for informed predictions of their future response to climatic forcing and geohazard prediction (Kääb and others, 2005). This is particularly relevant in the Caucasus Mountains, where numerous glaciers exist with varying degrees of debris cover and the vast majority of which are known to be retreating (cf. Stokes and others, 2006). Fatal glacier-related debris slides have also been reported in this region (Haeberli and others, 2004).

\section{RECENT GLACIER CHANGE IN THE CAUCASUS MOUNTAINS}

The Caucasus Mountains mark the boundary between Russia and Georgia, extending west-northwest to eastsoutheast from the Black Sea to the Caspian Sea (see Fig. 1). The mountain range extends for around $1300 \mathrm{~km}$ and contains several peaks above $4000 \mathrm{~m}$, the highest of which is Elbrus (5642 m). Estimates place the total glaciated area in the Caucasus Mountains at 1400-1805 km² (Bedford and Barry, 1995), with an average ice thickness of $\sim 75 \mathrm{~m}$ (Bazhev, 1989). 


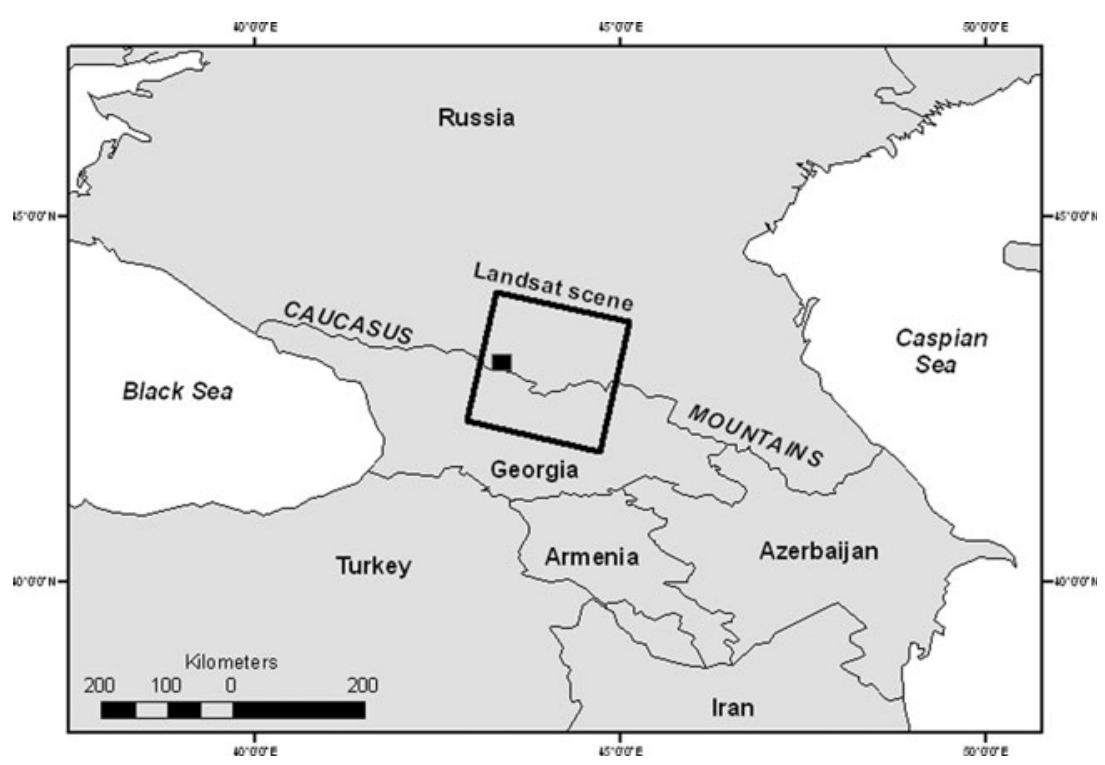

Fig. 1. Location map of the Caucasus Mountains showing the coverage of the Landsat satellite scene (path 131, row 70) and the location of our detailed study area in the Adylsu valley (black rectangle).

In total, there are over 2000 glaciers in the Caucasus, of which around 250 are temperate valley glaciers. Solomina (2000) reported evidence for widespread glacier retreat since the end of the Little Ice Age (LIA), although the timing of the most recent maximum is somewhat complex, with moraine lichenometry indicating maximum positions around AD 1300, 1700 and 1850 (Serebryannyy and others, 1984).

During the 1960s, the number of glaciers in retreat declined from $\sim 80 \%$ to $\sim 65 \%$, but the 1970 s saw an increasing number of glaciers in retreat, through to the early 1980s (Bedford and Barry, 1995). More recently, Stokes and others (2006) compared glacier terminus positions on satellite imagery of the Caucasus from 1985 and 2000. Of the 113 glaciers measured, $\sim 95 \%$ had retreated. Analysis of mass-balance measurements from Djankuat glacier and local and synoptic climate trends indicated that the recent retreat of Caucasus glaciers is being driven by an increase in summer air temperatures, with no compensating increase in winter precipitation (Shahgedanova and others, 2005).

Stokes and others (2006) also reported a $\sim 10 \%$ decrease in the surface area of debris-free ice between 1985 and 2000. They did not directly measure the spatial extent of debris cover on individual glaciers but speculated that it was increasing (as a percentage of glacier area) in tandem with glacier retreat. This assertion is supported by earlier field measurements on Djankuat glacier which indicated that the total area of debris cover increased from $3 \%$ to $10 \%$ of the entire glacier area between 1968 and 1999 (Popovnin and Rozova, 2002). Popovnin and Rozova (2002) also detected a general pattern whereby the more negative the mass balance, the higher the rate of debris accumulation on the glacier surface. Given that the vast majority of glaciers are in retreat in this region, this might imply that supraglacial debris cover is becoming more extensive elsewhere. To date, no data exist to verify or refute this.

In this paper, we build on previous work using satellite imagery (Stokes and others, 2006) and produce detailed maps of debris cover on six glaciers in the Adylsu valley, including Djankuat and Bashkara glaciers, where field investigation has been targeted by the Geographical Faculty of Moscow State University. We also map supra- and proglacial lake coverage across a larger area and compare the satellite image interpretations with the detailed field measurements.

\section{METHODS}

Three images of our study area were obtained, all from cloud-free scenes towards the end of the ablation season, and dating from 3 August 1985 (Landsat Thematic Mapper (TM)), 28 September 1991 (Landsat TM) and 5 September 2000 (Landsat Enhanced TM Plus (ETM+)). These images were geo-referenced (without correction for topographic distortion) and co-registered using ERDAS Imagine 8.7 software. The glacier outline and areal extent of debris cover on each glacier were manually digitized using a falsecolour composite image of TM bands 5, 4, 3 (red, green, blue), as recommended by Paul and others (2003). Although semi-automated techniques to map supraglacial debris cover have been developed recently (e.g. Paul and others, 2004), manual on-screen digitizing can be more accurate, especially where only small numbers of glaciers are being studied, as in this case. Error analysis of the digitizing at a scale of 1:30000 found the accuracy to be of the order of $\pm 25 \mathrm{~m}$ (i.e. the same glacier/debris-cover outline was independently digitized 20 times and the maximum distance between any two digitized positions was $\leq 25 \mathrm{~m}$ ). Once digitized, the image-processing software was used to measure the surface area of the glacier and the surface area of supraglacial debris cover.

We acknowledge that delineating the boundary between bare ice and debris-covered ice using imagery of this resolution $(25 \mathrm{~m})$ is difficult. It may be impossible, for example, to detect small areas of debris cover surrounded by bare glacier ice. Moreover, debris-covered glaciers often show a gradational transition from debris-free ice to debriscovered ice and this makes it difficult to define the margins of the debris cover (it should be remembered, however, that field-surveying of debris cover will also be hindered by this problem). As such, our mapping is essentially detecting 


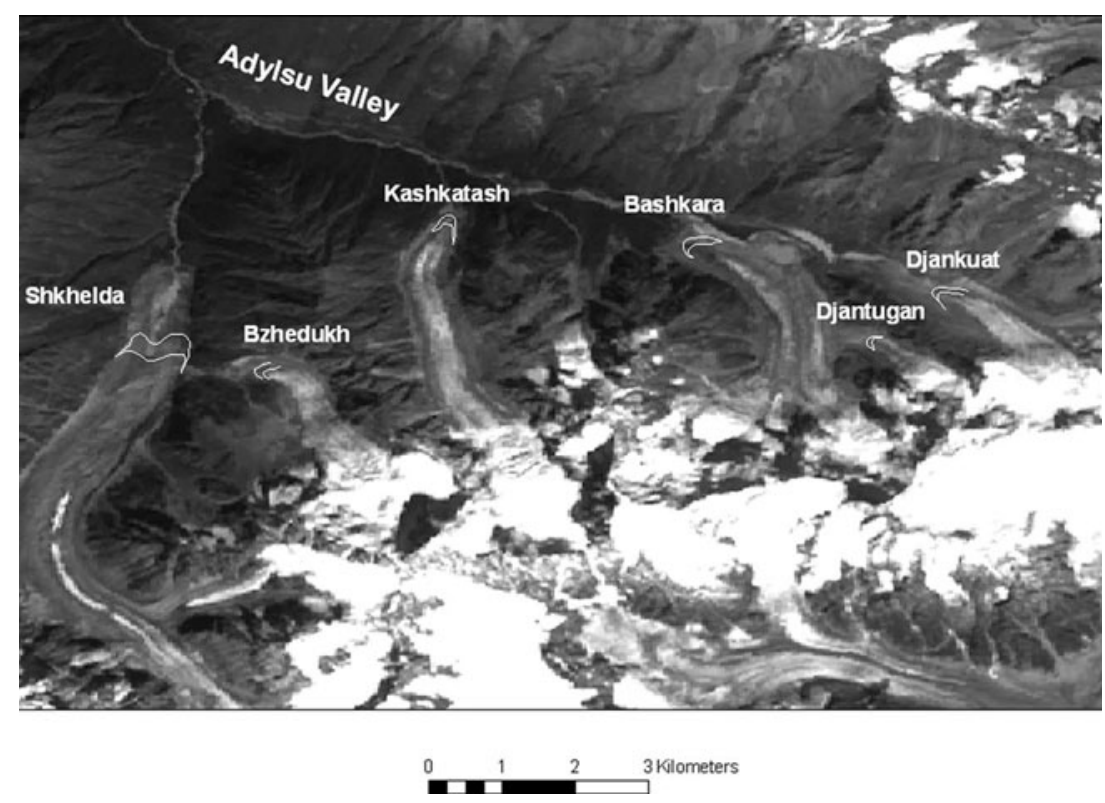

Fig. 2. Landsat ETM+ image of Adylsu valley from 2000, showing the location of the six glaciers investigated in this study. The glacier terminus positions in 1985 (outer limit) and 2000 (inner limit) are also shown. For clarity, the terminus position in 1991 is not shown. Note proglacial lake adjacent to the right flank of Bashkara glacier (see also Figs 4 and 5).

contiguous areas of generally thick debris cover which may contain small areas of exposed ice within it. The advantage of this, however, is that we are capturing the main changes in the extent of major areas of debris cover on the glaciers. Thus, although the mapping is unlikely to be entirely robust, it does reveal general patterns in the evolution of debris cover from which we can compare to field measurement. Additionally, we acknowledge that supraglacial debris is likely to fluctuate over much shorter timescales than our 6-9 year repeat measurements can detect, influenced by interannual variations in accumulation and ablation and non-climatic factors (e.g. rockfalls).

Proglacial lakes were readily identifiable on the satellite imagery because their spectral signature is in marked contrast to the glacier ice or debris cover that surrounds them. Rather than focus solely on the Adylsu valley, we broadened our mapping to the area covered by the whole Landsat scene from path 171, row 030.

In addition to our remote-sensing approach, detailed field mapping of supraglacial debris cover has been made on Djankuat glacier. The distribution of supraglacial debris cover has been surveyed at the end of the ablation season, and Popovnin and Rozova (2002) present incremental data from 1968, 1974, 1984, 1992, 1996 and 1999. We compare our results on the satellite imagery to the detailed data from Djankuat glacier, due to be updated in September 2006. Recently, detailed measurements have also been taken of proglacial lakes impounded against Bashkara glacier, one of the glaciers covered by our detailed mapping. These field data are a very useful way of verifying the accuracy of the satellite image interpretations.

\section{RESULTS}

\section{Glacier retreat and evolution of supraglacial debris cover}

The six glaciers in the Adylsu valley which were investigated are shown in Figure 2, which also shows their terminus positions in 1985 (outermost limit) and 2000 (innermost limit). It can be seen from Figure 2 that each of the six glaciers in the Adylsu valley has retreated, although at varying rates and distances. This information is detailed in Table 1, which shows the retreat distance and retreat rate for each glacier during each time interval.

It can be seen from Table 1 that a general pattern emerges whereby the larger glaciers have retreated a greater distance.

Table 1. Retreat distance and rates of six glaciers in the Adylsu valley, central Caucasus

\begin{tabular}{|c|c|c|c|c|c|}
\hline \multirow[t]{3}{*}{ Glacier name } & \multirow{3}{*}{$\begin{array}{c}\text { Surface area } \\
\text { in } 2000 \\
\mathrm{~km}^{2}\end{array}$} & \multirow{3}{*}{$\begin{array}{l}\text { Approx. altitude of } \\
\text { glacier terminus } \\
\text { m }\end{array}$} & \multicolumn{3}{|c|}{ Retreat distance $\pm 25 \mathrm{~m}$ (retreat rate) } \\
\hline & & & 1985-91 & $1991-2000$ & Total (1985-2000) \\
\hline & & & $\mathrm{m}\left(\mathrm{m} \mathrm{a}^{-1}\right)$ & $\mathrm{m}\left(\mathrm{ma}^{-1}\right)$ & $\mathrm{m}\left(\mathrm{ma}^{-1}\right)$ \\
\hline Shkhelda & 10.5 & 2260 & $186(31)$ & 171 (19) & 357 (24) \\
\hline Bzhedukh & 1.9 & 2650 & $36(6)$ & $59(7)$ & $95(6)$ \\
\hline Bashkara & 3.3 & 2560 & $90(15)$ & $20(2)$ & $110(7)$ \\
\hline Djantugan & 0.4 & 2990 & $26(4)$ & $29(3)$ & $55(4)$ \\
\hline Djankuat & 2.7 & 2700 & $10(2)$ & $25(3)$ & $35(2)$ \\
\hline
\end{tabular}




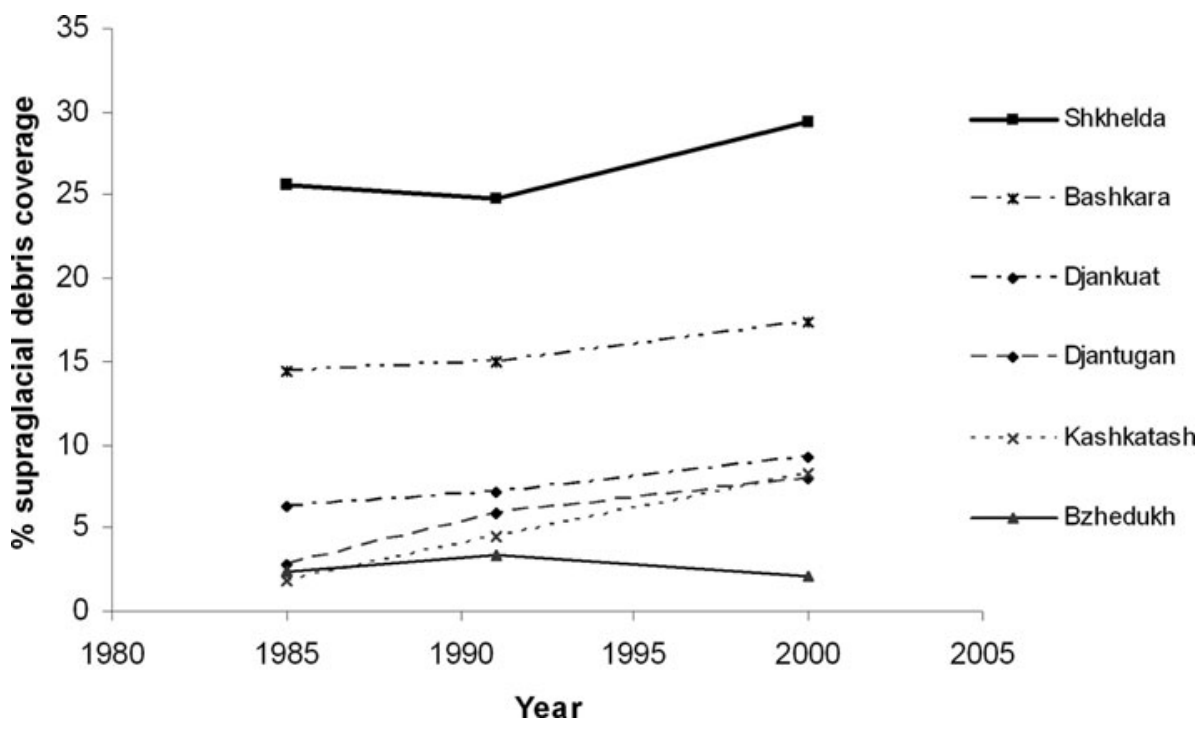

Fig. 3. Plot showing the general increase in debris cover of the six glaciers in the Adylsu valley, as a percentage of the glacier area.

This would be expected given that the larger glaciers extend to lower elevations within their respective valleys. In association with glacier retreat, supraglacial debris cover appears to be evolving to cover an ever-increasing area of the glaciers' surface. Our measurements indicate that between 1985 and 2000 supraglacial debris cover has increased as a percentage of the glacier surface area on all but one of the glaciers (Bzhedukh glacier). These results are shown in Figure 3, which plots the percentage of each glacier covered by supraglacial debris cover at each time increment.

On individual glaciers, supraglacial debris cover ranges from just a few per cent (e.g. Bzhedukh) to over 25\% (e.g. Shkhelda), but for all glaciers it generally increases 3-6\% between 1985 and 2000. On Djankuat glacier, for example, supraglacial debris cover increased from $6 \%$ to $9 \%$ between 1985 and 2000. We note that detailed field measurement of debris cover on this glacier by Popovnin and Rozova (2002) found an increase from 3\% to 10\% between 1968 and 1999, which is broadly consistent with our remote-sensing data. Indeed, the discrepancy may be explained by the fact that the detailed field surveying would have picked out smaller islands of debris cover which were beyond the resolution of the satellite imagery.

The increase in debris cover on each glacier is characterized by a progressive migration up-glacier. This can be clearly seen in Figure 4, which shows debris cover on the surface of Bashkara glacier at each time-step of the study period.

\section{Changes in proglacial/supraglacial lake coverage}

It can be seen in Figure 4 that glacier retreat and the increase in supraglacial debris cover on Baskhara glacier has also been accompanied by the emergence and growth of proglacial lakes. The remote mapping clearly indicates the growth of these lakes since 1985 as a recent phenomenon. Indeed, detailed measurements of these lakes indicate that they have progressively increased in size and depth during the last two decades. Figure 5 a shows the areal extent of Lapa lake, adjacent to the terminus of Bashkara glacier, and Figure $5 b$ is a photograph of the lake from 2005 (see Fig. 4 for location).
We also mapped the occurrence of proglacial and supraglacial lakes across the whole area covered by the Landsat scene (path 171, row 30). A synoptic assessment across this region has never been undertaken before, but our results indicate that the growth of lakes in the Adylsu valley follows a regional trend. Table 2 shows the number and areal extent of lakes in 1985 compared to 2000.

The data in Table 2 indicate that there were sixteen lakes in 1985 , but by 2000 two of these had disappeared, six had decreased in size and eight had increased in size. Moreover, a further ten new lakes had appeared in 2000 that did not exist in 1985. In summary, the total lake area in 1985 was $0.2423 \mathrm{~km}^{2}$ and this increased to $0.3815 \mathrm{~km}^{2}$ in 2000 , representing a $57 \%$ increase in lake surface area in the study region.

\section{DISCUSSION}

With one exception (Bzhedukh glacier), mapping of six neighbouring glaciers indicates that glacier retreat is being accompanied by an increase in the proportion of each glacier covered by supraglacial debris. In general, our results indicate a $3-6 \%$ increase in debris cover over the period 1985-2000.

The presence of supraglacial debris can have a profound influence on ablation rates (e.g. Nakawo and Rana, 1999). A thin layer of debris (generally $<1-2 \mathrm{~cm}$ ) will lower the albedo of the glacier surface, causing it to absorb more shortwave radiation. This results in an increase in ablation of the underlying and adjacent ice, compared to 'cleaner' ice nearby. Thicker debris layers $(>5-10 \mathrm{~mm})$, however, have the effect of shielding the underlying ice from incoming solar radiation and this can greatly reduce ablation, compared to cleaner ice nearby (cf. Østrem, 1959; Bozhinskiy and others, 1986; Benn and Evans, 1998). Thus, the highest ablation rates are likely to be focused in areas of thin, patchy debris and/or at the up-glacier limit of the supraglacial debris cover.

The evolution of the debris cover on the glaciers in our study area is characterized by a progressive up-glacier migration of pre-existing coverage (see Fig. 4). This process, accompanied by glacier retreat, is described as 'backwasting' (Benn and Evans, 1998) and occurs when ablation 

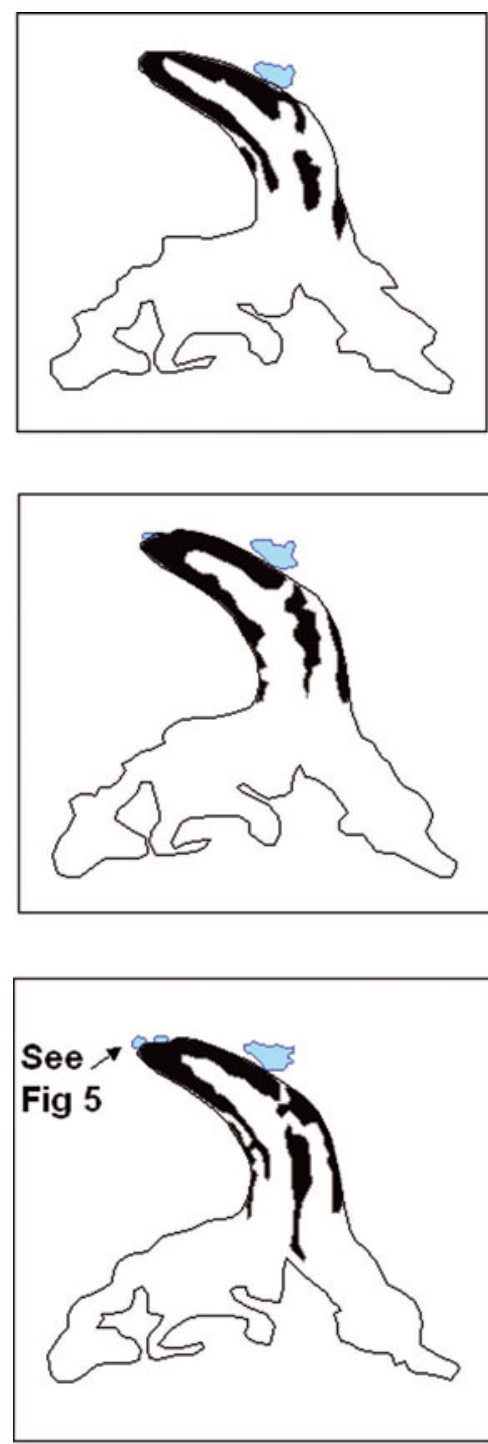

2000

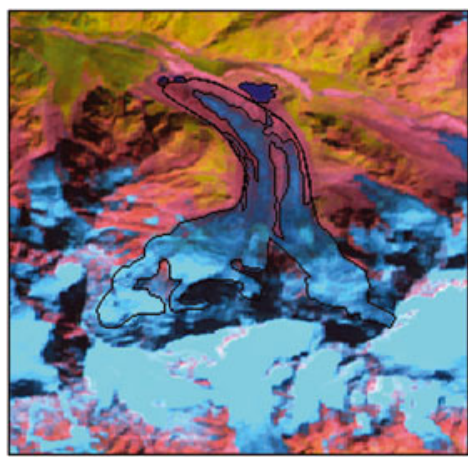

\section{Kilometers}

Fig. 4. Incremental changes in glacier surface area and supraglacial debris cover on Bashkara glacier. Also note the emergence and growth of proglacial lakes adjacent to the glacier terminus and shaded in light grey, shown in Figure 5.

at the snout is greatly reduced by the presence of the debris cover and melting is focused on the debris-free ice on the steeper slopes and at the up-glacier limit of the debris cover. The expansion of supraglacial debris, therefore, is primarily driven by the thinning of the glacier and the progressive exposure of englacial debris at the up-glacier limits of the existing debris cover, where ablation is most intense due to the influence of thinner, patchy debris cover. A similar pattern of up-glacier migration and a change in the locus of maximum ablation has also been detected on Tasman Glacier, New Zealand (Kirkbride and Warren, 1999). Kirkbride and Warren (1999) also report the development of an ice-contact proglacial lake adjacent to this glacier, resulting from thermokarst processes.

The process of glacier thinning can lead to other positive feedbacks whereby surface lowering of the lateral margins of the glacier, including in the accumulation area, can lead to slope instability. Additionally, a warming climate can result in permafrost melting which induces instabilities in the highaltitude rock faces. Indeed, examples of this have recently been observed on Djankuat glacier in 2001 and 2003 (see Fig. 6). The 2003 rock avalanche stretched across the whole accumulation area of the glacier and dramatically increased supraglacial debris coverage. This additional supply of supraglacial debris may also play a role in increasing the overall coverage on the Caucasus glaciers.

Towards the lower limits of the glacier where debris cover is at its thickest, ablation can be greatly reduced and the presence of a thick debris mantle may decouple the glacier from climatic forcing such that debris-covered glaciers respond more slowly to climatic changes (Benn and Evans, 1998; Mattson, 2000; Thompson and others, 2000). It would appear, however, that the glaciers in the Adylsu valley are continuing to respond to the recently observed warming trend in the region (Shahgedanova and others, 2005) because glacier retreat is continuing, i.e. the shielding effect of the increased supraglacial debris at the glacier snouts is not enough to offset the retreat trend. It may be that the debris cover is preventing what would otherwise be an even more rapid retreat because supraglacial debris 

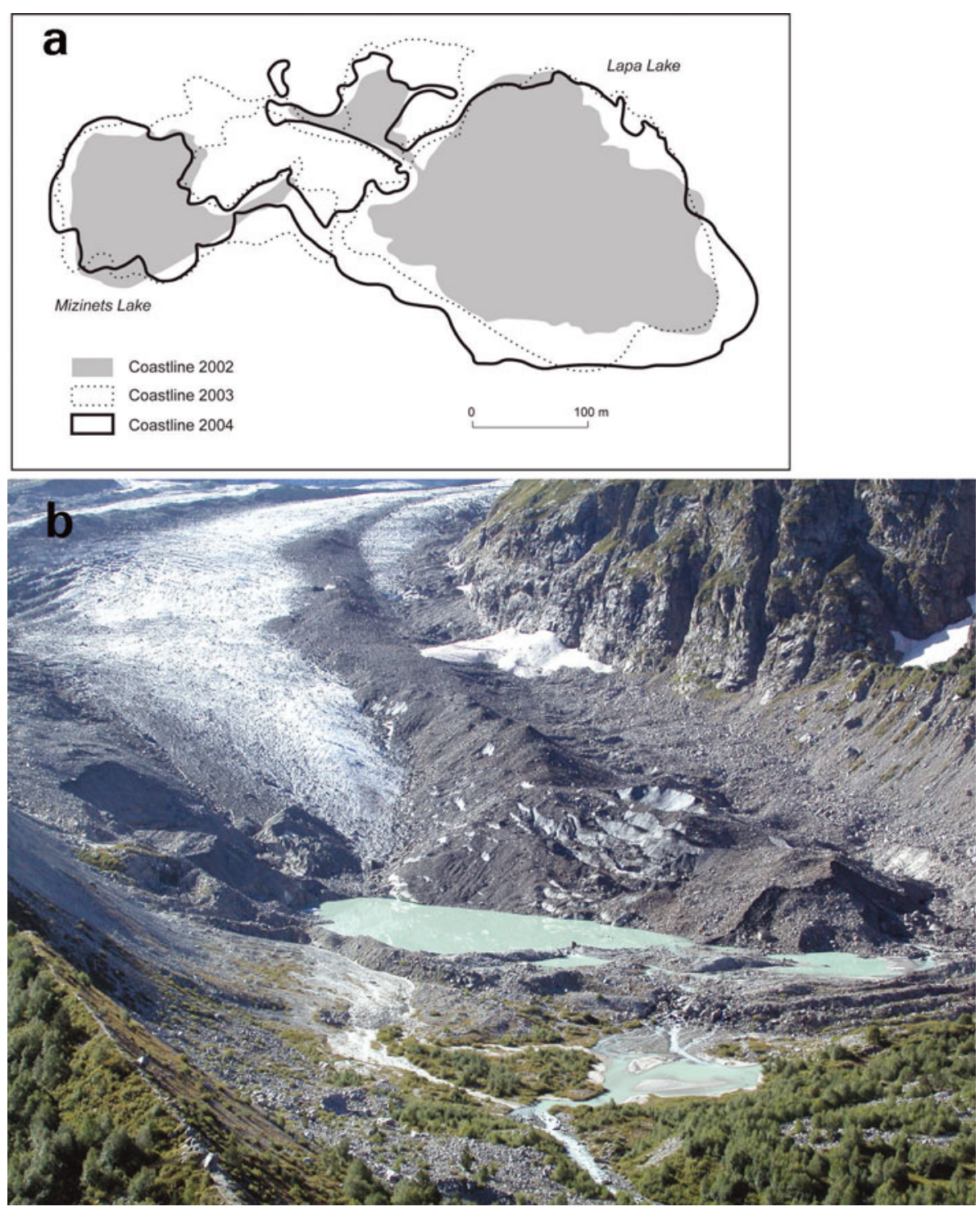

Fig. 5. (a) Recent $(2002,2003,2004)$ expansion and joining of two lakes (Lapa and Mizinets) at the terminus of Bashkara glacier, shown in (b). These lakes did not exist in 1985 and continue to enlarge (see Fig. 4 for location).

cover can impart an important control on ice flow and glacier dynamics. In reducing melting during the ablation season, debris cover can reduce the infiltration of surface meltwater to the bed and thereby modify the subglacial hydrology and glacier flow. Mattson (2000), for example, found that debris cover on Dome Glacier in the Canadian Rocky Mountains apparently acts to subdue subglacial hydrology and stream-flow. Annual variances in volumetric meltwater discharge from this glacier were only around $1 \%$ during the study period, compared to $24 \%$ for the neighbouring and largely debris-free Athabasca Glacier. As a result, Mattson (2000) speculated that debris-covered glaciers may not be as sensitive to climate change as debrisfree glaciers, and a similar conclusion was reached by Thompson and others (2000), who found that the debriscovered Ghiacciaio del Miage in the Italian Alps had retreated less than debris-free glaciers in the same region. Exploration of the relationship between debris-cover thickness and extent, mass balance and frontal variations is clearly warranted, and field measurement of the surface energy balance on and adjacent to debris-covered ice should prove fruitful.
The retreat of the Caucasus glaciers and the increase in their supraglacial debris cover is also linked to the observed increase in the number and areal extent of supra- and proglacial lakes. Debris-covered snouts may become separated from more rapidly ablating ice further up-glacier and eventually stagnate. Ice cored (and non-ice-cored) moraine can then serve as an effective barrier to meltwater runoff and can lead to the development of proglacial and supraglacial lakes (cf. Richardson and Reynolds, 2000; Chikita and others, 2001). The potential instability of such lakes may pose a serious threat to human activity downstream (Konrad, 1998; Richardson and Reynolds, 2000).

Our analysis indicates that both the total number of lakes and their surface area have increased dramatically in this region since 1985 (see Fig. 5; Table 2). This is similar to the situation reported by Ageta and others (2000) who found that both supraglacial and proglacial lakes had expanded in the Bhutan Himalaya between the 1950s and 1998. Detailed field measurements of the lakes adjacent to Bashkara glacier (Fig. 5) confirm the regional trend, showing a progressive enlargement and deepening. Many of the lakes, as in the case of Bashkara glacier, lie immediately 
Table 2. Comparison between the number and size of proglacial lakes on Landsat scene path 171, row 030 in 1985 and 2000

\begin{tabular}{|c|c|c|c|c|c|c|c|}
\hline \multirow[t]{2}{*}{ No. } & \multirow[t]{2}{*}{ Glacier catchment } & \multirow{2}{*}{$\begin{array}{c}\text { Lat. } \\
\text { 。 }\end{array}$} & \multirow{2}{*}{$\begin{array}{c}\text { Long. } \\
\circ\end{array}$} & \multirow{2}{*}{$\begin{array}{c}\text { Surface area } \\
\text { in } 1985 \\
\mathrm{~km}^{2}\end{array}$} & \multirow{2}{*}{$\begin{array}{c}\text { Surface area } \\
\text { in } 2000 \\
\mathrm{~km}^{2}\end{array}$} & \multirow{2}{*}{$\begin{array}{c}\text { Change in } \\
\text { surface area } \\
\mathrm{km}^{2}\end{array}$} & \multirow[t]{2}{*}{$\%$ change $^{\dagger}$} \\
\hline & & & & & & & \\
\hline 1 & Mickelchiran & 42.51 & 43.39 & 0.0122 & 0 & -0.0122 & -100 \\
\hline 2 & Dzhikiugankez & 42.55 & 43.39 & 0.0071 & 0.0118 & 0.0047 & 66 \\
\hline 3 & SU4G08005013 & 42.63 & 43.34 & 0.0022 & 0.0039 & 0.0017 & 77 \\
\hline 4 & Kestanty east & 42.99 & 43.31 & 0.0233 & 0.0212 & -0.0021 & -9 \\
\hline 5 & Sabalyk & 42.84 & 43.29 & 0.0031 & 0.0046 & 0.0015 & 47 \\
\hline 6 & SU4G08005109 & 42.98 & 43.27 & 0.0024 & 0.0068 & 0.0044 & 183 \\
\hline 7 & Kichkinekol $^{*}$ & 42.31 & 43.25 & 0.0118 & 0.008 & -0.0038 & -32 \\
\hline 8 & Kichkinekol $^{*}$ & 42.34 & 43.24 & 0.0016 & 0.0025 & 0.0009 & 58 \\
\hline 9 & Donguz-Orun & 42.50 & 43.22 & 0.0639 & 0.0643 & 0.0004 & 1 \\
\hline 10 & Bashkara & 42.73 & 43.21 & 0.0543 & 0.0524 & -0.0019 & -4 \\
\hline 11 & SU4G08006009 & 42.91 & 43.21 & 0.0064 & 0.0042 & -0.0022 & -34 \\
\hline 13 & Shtavler ${ }^{*}$ & 42.36 & 43.16 & 0.0272 & 0.0204 & -0.0068 & -25 \\
\hline 14 & Kulak north & 42.96 & 43.15 & 0.0017 & 0.0109 & 0.0092 & 545 \\
\hline 15 & Ulluaz & 43.27 & 43.09 & 0.0011 & 0 & -0.0011 & -100 \\
\hline 16 & Ulluaz & 43.27 & 43.09 & 0.0033 & 0.0056 & 0.0023 & 70 \\
\hline 17 & Dzhikiugankez & 42.53 & 43.38 & & 0.0050 & 0.0050 & +100 \\
\hline 18 & Dzhikiugankez & 42.53 & 43.38 & & 0.0616 & 0.0616 & +100 \\
\hline 19 & Little Azau & 42.45 & 43.28 & & 0.0240 & 0.0240 & +100 \\
\hline 20 & Kichkinekol $^{*}$ & 42.35 & 43.27 & & 0.0120 & 0.0120 & +100 \\
\hline 21 & Kichkinekol $^{*}$ & 42.36 & 43.24 & & 0.0239 & 0.0239 & +100 \\
\hline 22 & Bashkara (Fig. 5) & 42.72 & 43.21 & & 0.0060 & 0.0060 & +100 \\
\hline 23 & Bashkara (Fig. 5) & 42.72 & 43.21 & & 0.0032 & 0.0032 & +100 \\
\hline 24 & Shtavler & 42.31 & 43.12 & & 0.0022 & 0.0022 & +100 \\
\hline 25 & SUST09105221 & 42.54 & 43.12 & & 0.0052 & 0.0052 & +100 \\
\hline 26 & Bokos & 43.71 & 42.75 & & 0.0029 & 0.0029 & +100 \\
\hline \multicolumn{4}{|c|}{ Total area in $1985\left(\mathrm{~km}^{2}\right)$} & 0.2423 & & & \\
\hline \multicolumn{4}{|c|}{$\%$ change in lake surface area } & & $+57.4 \%$ & & \\
\hline
\end{tabular}

Note: Where glacier names are unknown, the World Glacier Monitoring Service code is used.

*Nearest 'named' glacier.

${ }^{\dagger}$ A change of $+100 \%$ indicates a new lake and a change of $-100 \%$ that the lake has disappeared.

adjacent to debris-covered ice, either at the terminus of the glaciers or perched adjacent to their lateral margins. Thus, the recent thinning and retreat of the glaciers is leading to ponding of meltwater against relatively recent terminal and lateral moraines. Given that the mid-1980s to early 1990s were generally more favourable for Caucasus glaciers (i.e. less negative mass balance than current trends), it might be that many of the lakes have formed since the early 1990s during a period of more rapid retreat.

Continuation of this trend is therefore likely to lead to more lakes emerging in the region, and the progressive enlargement and filling of existing lakes. Once such lakes have developed, their thermal properties ensure that progressive expansion is achieved through the melting and subsidence of the dead ice beneath them (thermokarst) and the melting of adjacent ice, as well as thermally induced calving (Chikita and others, 1999; Sakai and others, 2000; Kääb and Haeberli, 2001). We suggest that it is these thermokarst processes that are leading to the observed expansion of the lakes adjacent to Bashkara glacier (Fig. 4). Additionally, supraglacial lakes may form at the up-glacier limit of the debris cover because this is where ablation is focused and may create a surface depression on the glacier surface (Konrad, 1998; Naito and others, 2000). The development of such lakes is also determined by the overall surface gradient of the glacier, with low surface slopes $\left(<10^{\circ}\right)$ more favourable for lake development (Reynolds, 2000).

Given that many of the glacial catchments in the Caucasus feed directly into larger valleys which house small settlements and towns, this is a concern. Indeed, recently there has been a glacier-related rock/mudslide which led to major loss of life in this region (Haerberli and others, 2004). Although this was not attributable to a supra-/proglacial lake outburst, it emphasizes the close proximity of human activities to these glacial systems and their vulnerability to glacier-related hazards.

\section{CONCLUSIONS}

In this paper, we report local changes on six neighbouring glaciers undergoing retreat in the Adylsu valley, focusing specifically on the evolution of supraglacial debris cover and the evolution of supra- and proglacial lakes. We also extend our investigation of supra- and proglacial lakes beyond this valley to a much larger area of the central Caucasus. Mapping from satellite imagery (covering the period 19852005) and field surveys (e.g. Popovnin and Rozova, 2002) leads us to the following conclusions: 

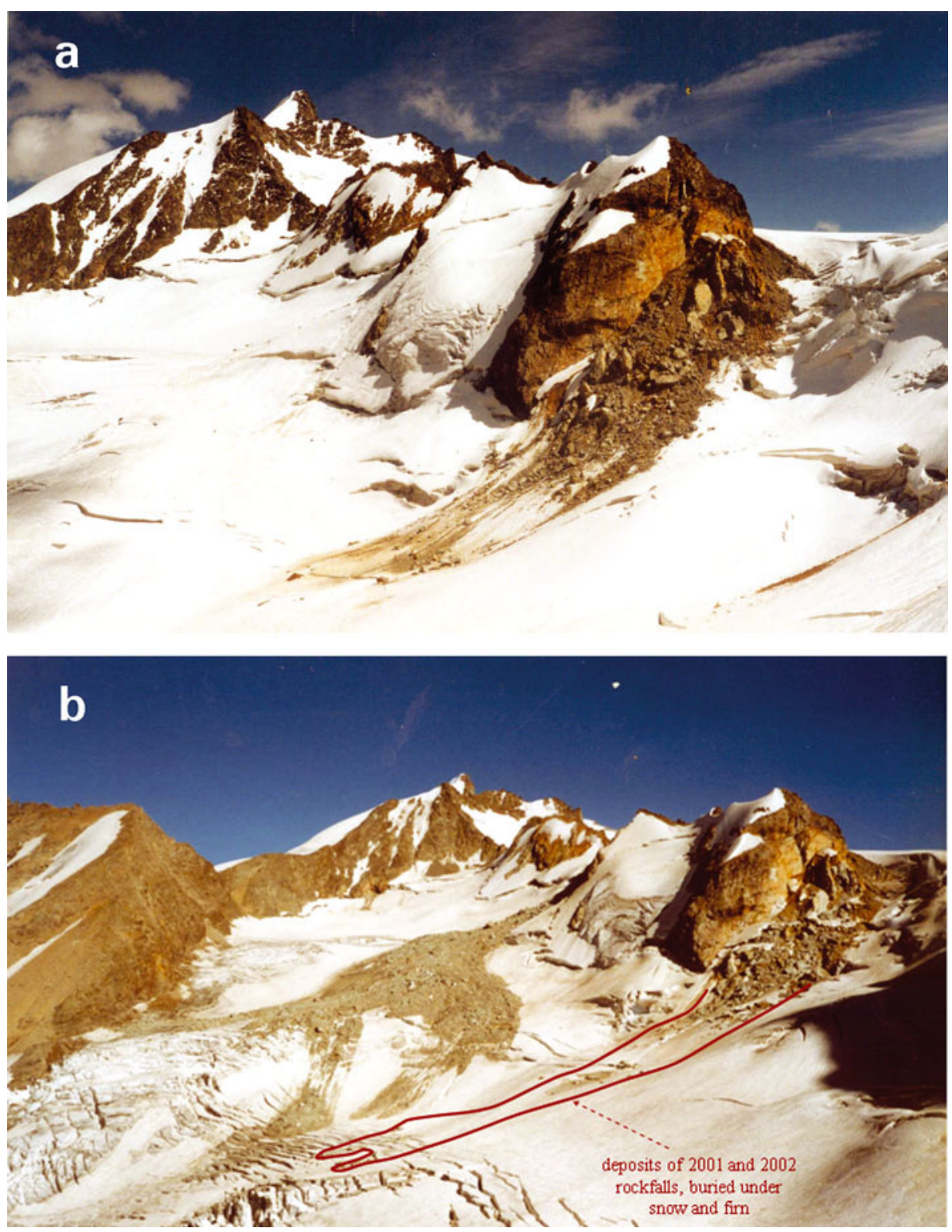

Fig. 6. Photographs of two rock avalanches on Djankaut glacier in 2001 (a) and 2003 (b), thought to be induced by glacier thinning in the accumulation area and permafrost melting which induce instabilities in the high-altitude rock face.

Glacier retreat and thinning is accompanied by a progressive and consistent increase in the percentage of supraglacial debris cover on each glacier, with the exception of one very small glacier where accurate mapping is more difficult

In general, supraglacial debris cover has increased 3-6\% on each glacier and is characterized by a gradual migration of existing debris cover up-glacier

Glaciers in the Caucasus mountains appear to be undergoing a process of backwasting whereby the debris-covered snouts are largely stagnant, albeit in retreat, but ablation and thinning is focused at the upglacier limit of the debris cover, rather than the terminus

Glacier thinning and shrinkage (in addition to permafrost melt) increases the likelihood of slope failure immediately adjacent to the glacier (including the accumulation area), leading to the addition of further debris on to glacier surfaces

The recent increase in glacier retreat and thinning has led to the ponding of meltwater in lakes impounded by recent (late 1980s?) terminal and lateral moraines. The total number of supra- and proglacial lakes in our wider study area has increased from 16 to 24 , representing a $57 \%$ increase in total lake area coverage

The progressive increase in debris cover and glacial lake coverage is likely to exert a profound influence on the future response of these glaciers to climate change (Sakai and others, 2000; Thompson and others, 2000). Detailed measurement of the interactions between debris-cover thickness and extent and the surface energy balance is required to elucidate the links between debris cover and glacier mass balance. In addition, continued monitoring of supra- and proglacial lakes would appear to be a prudent precaution against potential glacier-related hazards (Richardson and Reynolds, 2000). 


\section{ACKNOWLEDGEMENTS}

This work was funded by the School of Human and Environmental Science at The University of Reading and the Royal Society Joint Project Scheme (2005/R2-JP/H3088300). The ongoing field monitoring of Djankuat and Bashkara glaciers is supported by the Russian Foundation for Basic Research (06-05-64094a). We thank C. Huggel, an anonymous reviewer and the scientific editor, A. Kääb, for instructive comments on the manuscript.

\section{REFERENCES}

Ageta, Y. and 6 others. 2000. Expansion of glacier lakes in recent decades in the Bhutan Himalayas. IAHS Publ. 264 (Symposium at Seattle 2000 - Debris-Covered Glaciers), 165-175.

Barry, R.G. 2006. The status of research on glaciers and global glacier recession: a review. Progr. Phys. Geogr., 30(3), 285-306.

Bazhev, A.B. 1989. Modern glaciation: snow-ice resources. In Badenkov, Yu.P., ed. Guidebook for the pre-conference excursion 'Transformation of mountain environments: regional development and sustainability; consequences for global change'. Moscow, USSR Academy of Sciences. Institute of Geography.

Bedford, D.P. and R.G. Barry. 1995. Glacier trends in the Caucasus, 1960s to 1980s. Phys. Geogr., 15(5), 414-424.

Benn, D.I. and D.J.A. Evans. 1998. Glaciers and glaciation. London, Arnold.

Benn, D.I., S. Wiseman, and C.R. Warren. 2000. Rapid growth of a supraglacial lake, Ngozumpa Glacier, Khumbu Himal, Nepal. IAHS Publ. 264 (Symposium at Seattle 2000 - Debris-Covered Glaciers), 177-185.

Bozhinskiy, A.N., M.S. Krass and V.V. Popovnin. 1986. Role of debris cover in the thermal physics of glaciers. J. Glaciol., 32(111), 255-266.

Chikita, K., J. Jha and T. Yamada. 1999. Hydrodynamics of a supraglacial lake and its effect on the basin expansion: Tsho Rolpa, Rolwaling Valley, Nepal Himalaya. Arct. Antarct. Alp. Res., 31(1), 58-70.

Chikita, K., J. Jha and T. Yamada. 2001. Sedimentary effects on the expansion of a Himalayan supraglacial lake. Global Planet. Change, 28(1-4), 23-34.

Fischer, L., A. Kääb, C. Huggel and J. Noetzli. 2006. Geology, glacier retreat and permafrost degradation as controlling factors of slope instabilities in a high-mountain rock wall: the Monte Rosa east face. Natur. Hazards Earth Syst. Sci. (NHESS), 6(5), 761-772.

Haeberli, W. and 7 others. 2004. The Kolka-Karmadon rock/ice slide of 20 September 2002: an extraordinary event of historical dimensions in North Ossetia, Russian Caucasus. J. Glaciol., 50(171), 533-546.

Kääb, A. and W. Haeberli. 2001. Evolution of a high-mountain thermokarst lake in the Swiss Alps. Arct. Antarct. Alp. Res., 33(4), 385-390.

Kääb, A. and 10 others. 2005. Remote sensing of glacier- and permafrost-related hazards in high mountains: an overview. Natur. Hazards Earth Syst. Sci. (NHESS), 5, 527-554.

Kaser, G., I. Juen, C. Georges, J. Gomez and W. Tamayo. 2003. The impact of glaciers on the runoff and the reconstruction of mass balance history from hydrological data in the tropical Cordillera Blanca, Peru. J. Hydrol., 282(1-4), 130-144.

Kirkbride, M.P. and C.R. Warren. 1999. Tasman Glacier, New Zealand: 20th-century thinning and predicted calving retreat. Global Planet. Change, 22(1-4), 11-28.
Konrad, S.K. 1998. Possible outburst floods from debris-covered glaciers in the Sierra Nevada, California. Geogr. Ann., 80A(3-4), 183-192.

Mattson, L.E. 2000. The influence of a debris cover on the midsummer discharge of Dome Glacier, Canadian Rocky Mountains. IAHS Publ. 264 (Symposium in Seattle 2000 - DebrisCovered Glaciers), 25-33.

Naito, N., M. Nakawo, T. Kadota and C.F. Raymond. 2000. Numerical simulation of recent shrinkage of Khumbu Glacier, Nepal Himalayas. IAHS Publ. 264 (Symposium at Seattle 2000 Debris-Covered Glaciers), 245-254.

Nakawo, M. and B. Rana. 1999. Estimate of ablation rate of glacier ice under a supraglacial debris layer. Geogr. Ann., 81A(4), 695-701.

Østrem, G. 1959. Ice melting under a thin layer of moraine, and the existence of ice cores in moraine ridges. Geogr. Ann., 41(4), 228-230.

Paul, F., C. Huggel, A. Kääb, T. Kellenberger and M. Maisch. 2003. Comparison of TM-derived glacier areas with higher resolution data sets. EARSeL eProc., 2(1), 15-21.

Paul, F., C. Huggel and A. Kääb. 2004. Combining satellite multispectral image data and a digital elevation model for mapping debris-covered glaciers. Remote Sens. Environ., 89(4), 510-518.

Popovnin, V.V. and A. Rozova. 2002. Influence of sub-debris thawing on ablation and runoff of the Djankuat Glacier in the Caucasus. Nord. Hydrol., 33(1), 75-94.

Reynolds, J.M. 2000. On the formation of supraglacial lakes on debris-covered glaciers. IAHS Publ. 264 (Symposium at Seattle 2000 - Debris-Covered Glaciers), 153-161.

Richardson, S.D. and J.M. Reynolds. 2000. Degradation of icecored moraine dams: implications for hazard development. IAHS Publ. 264 (Symposium at Seattle 2000 - Debris-Covered Glaciers), 187-197.

Rignot, E., A. Rivera and G. Casassa. 2003. Contribution of the Patagonian icefields of South America to sea level rise. Science, 302(5644), 434-437.

Sakai, A., N. Takeuchi, K. Fujita, and M. Nakawo. 2000. Role of supraglacial ponds in the ablation process of a debris-covered glacier in the Nepal. IAHS Publ. 264 (Symposium at Seattle 2000 - Debris-Covered Glaciers), 119-130.

Serebryannyy, L.R., N.A. Golodkovskaya, A.V. Orlov, E.S. Malyasova and E.O. II'ves. 1984. Kolebaniya lednikov i protsessi morenonakopleniya na Tsentral'nom Kavkaze [Glacier variations and moraine accumulation processes in the Central Caucasus]. Moscow, Nauka.

Shahgedanova, M., C.R. Stokes, S.D. Gurney and V.V. Popovnin. 2005. Interactions between mass balance, atmospheric circulation and recent climate change on the Djankuat glacier, Caucasus Mountains. J. Geophys. Res., 110(D4), D04108. (10.1029/2004JD005213.)

Solomina, O.N. 2000. Retreat of mountain glaciers of northern Eurasia since the Little Ice Age maximum. Ann. Glaciol., 31, 26-30.

Stokes, C.R., S.D. Gurney, M. Shahgedanova and V. Popovnin. 2006. Late-20th-century changes in glacier extent in the Caucasus Mountains, Russia/Georgia. J. Glaciol., 52(176), 99-109.

Thompson, M.H., M.P. Kirkbride and B.W. Brock. 2000. Twentieth century surface elevation change of the Miage Glacier, Italian Alps. IAHS Publ. 264 (Symposium in Seattle 2000 - DebrisCovered Glaciers), 219-225. 